\title{
Celovito obvladovanje kakovosti v javnem sektorju
}

UDK: 35.088:331.101.6

\section{Žiga Andoljšek}

Univerza v Ljubljani, Fakulteta za upravo

ziga.andoljsek@fu.uni-lj.si

\section{IZVLEČEK}

Namen prispevka je predstaviti celovito obvladovanje kakovosti (TOM) v javni upravi. Teoretični definiciji kakovosti sledi pojasnitev razlike med kontrolo in obvladovanjem kakovosti kot vse pomembnejši sestavini procesov v storitvenih organizacijah. Nadrobno so pojasnjene tudi tri osnovne sestavine obvladovanja kakovosti: osredotočenje na stranko, stalno izboljševanje procesov in celovito sodelovanje zaposlenih v timih. Pri prenosu spoznanj celovitega obvladovanja kakovosti v javni sektor pa ne moremo mimo nekaterih omejitev in značilnosti, ki jih je treba upoštevati.

Ključne besede: javni sektor, kakovost javnega sektorja, merjenje kvalitete, celovito obvladovanje kakovosti (TQM)

\section{Uvod}

Zaradi vse večje pomembnosti javnega sektorja ter izboljševanja njegove učinkovitosti in uspešnosti lahko tudi $v$ javnem sektorju opazimo zgledovanje po zasebnem sektorju. Sodelovanje javnega in zasebnega sektorja $\vee$ obliki javnozasebnega partnerstva (PPP) je uveljavljeno. Predvsem v praksi tujih držav pa opazimo, da se tudi načini vodenja zasebnega sektorja prenašajo $v$ javni sektor. Eden takih primerov je teorija celovitega obvladovanja kakovosti.

Cilj članka je predstaviti celovito obvladovanje kakovosti širši publiki. Po teoretičnem delu bomo navedli nekatere posebnosti javnega sektorja, ki od teoretikov in praktikov zahtevajo poseben pristop $k$ uvajanju omenjene teorije $v$ organizacije javnega sektorja. Na tem mestu bomo omenili razlikovanje med proizvodi in storitvami, stranko in državljanom ter možnosti za timsko delo. Vse to bomo skušali postaviti v okvir celovitega obvladovanja kakovosti (Total Quality Management TQM).

Teorija celovitega obvladovanja kakovosti je zbir načel in tehnik za neprestane izboljšave procesov $v$ organizaciji od najvišjih nivojev pa do najnižjih s ciljem popolnoma zadovoljiti stranko s kakovostnim proizvodom, procesi, organizacijo in zaposlenimi (Henry, 1999, str. 219). Omenjena teorija je danes $\vee$ velikem razmahu tako $v$ 
zasebnem kot $\vee$ javnem sektorju. $\vee$ Združenih državah Amerike pravijo, da prinaša »nekaj socialnega čuta v ekonomsko teorijo" (Hackman idr., 1995, str. 309).

V Slovarju slovenskega knjižnega jezika je beseda »kakovost« opredeljena kot »kar opredeljuje kaj glede na veliko mero pozitivne lastnosti «. V organizacijski literaturi pa najdemo mnogo različnih definicij besede "kakovost".

Juran, strokovnjak na področju kakovosti, je opredelil kakovost kot primernost za uporabo (Žnidaršič, 1990, str. 5-10). Ameriško združenje za nadzor kakovosti je definiralo kakovost kot skupek lastnosti in značilnosti izdelka oz. storitve, ki vplivajo na njegovo sposobnost, da zadovolji izražene ali naznačene potrebe (Kotler, 1996, str. 56). Kakovost je celokupnost značilnosti in karakteristik izdelka ali storitve, ki se nanaša na njeno zmožnost, da zadovolji določene zahteve, potrebe ali pričakovanja stranke oziroma trga (Marolt, 1994).

Nov način vodenja javne uprave je usmerjen $v$ čim kakovostnejše zadovoljevanje javnih potreb. Koncepti, metode in tehnike so preneseni iz podjetništva in so vključeni v vodenje javne uprave. Cilj nove javne uprave je čim večja učinkovitost in uspešnost javne uprave. Slika 1 kaže usmerjenost javne uprave na več pomembnih področij. Kot eno izmed področij lahko opazimo tudi delovanje za celovito obvladovanje kakovosti.

\section{Slika 1: Nova javna uprava}

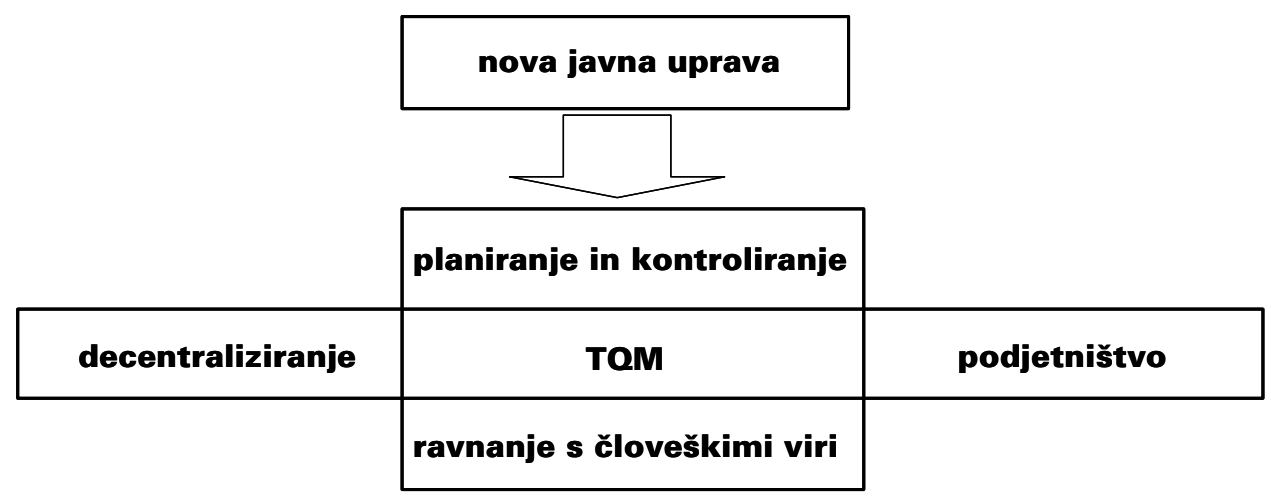

Vir: Goller idr., 1996, str. 136.

Sistem kakovosti, ki temelji na stalnem izboljševanju kakovosti procesov ter storitev in proizvodov je eden izmed konceptov, ki je bil prenesen iz podjetij v javno upravo. Sistem pomeni proces stalnih izboljšav pri spreminjanju vložkov (input) v izložke (output). Obsega interno in eksterno dimenzijo organizacije. Zadeva celotno pot storitve ali izdelka od začetka do konca in odnose znotraj in zunaj organizacije. Obvladovanje celovite kakovosti je definirano kot razvijajoč se sistem, ki je osredotočen na stalno izboljševanje kakovosti izdelkov in storitev, da bi se povečala zadovoljstvo 


\section{Žiga Andoljšek}

\section{Celovito obvladovanje kakovosti v javnem sektorju}

kupcev in uspešnost organizacije oz. ustanove. Poudarek je na sodelovanju zaposlenih s ciljem doseči čim boljši rezultat.

Z vpeljavo ustreznega sistema kakovosti lahko organizacija doseže tudi znižanje stroškov poslovanja. Stalno izboljševanje, spodbujanje in vključevanje zaposlenih v reševanje problemov omogoča, da si organizacija pridobi zaupanje strank, zniža stroške ter poveča zadovoljstvo, učinkovitost in uspešnost.

\section{Celovito obvladovanje kakovosti in njegove značilnosti}

\subsection{Opredelitev celovitega obvladovanja kakovosti}

Izboljševanje kakovosti izdelkov in storitev, stalno zmanjševanje stroškov in rast produktivnosti so se izkazali kot osnovni stebri dolgoročnega obstoja podjetij in ustanov. $\vee$ zadnjem času tudi $v$ svetu podjetja in ustanove izboljšujejo kakovost izdelkov in storitev ter $s$ tem uspešnost, ker uporabljajo načelo t. i. obvladovanja celovite kakovosti (TOM). Definicija TQM, ki so jo postavili ugledni profesorji vodilnih univerz $\vee$ ZDA, ugledni svetovalci s področja kakovosti in devet predsednikov velikih ameriških korporacij, je (Verbič, 1994, str. 33-34): "Celovito obvladovanje kakovosti je sistem ravnanja z ljudmi, ki si prizadeva za večje zadovoljstvo strank ob čedalje nižjih realnih stroških. Celovito obvladovanje kakovosti je celovit sistemski pristop in sestavni del strategije, ki deluje horizontalno na vseh funkcijah in sektorjih, vključuje vse zaposlene od vrha do dna in sega nazaj $\vee$ verigo dobaviteljev ter naprej $v$ verigo odjemalcev. Celovita kakovost poudarja izobraževanje in usposabljanje za nenehno spreminjanje kot ključ za uspeh organizacije." Definicija nadalje pravi, da se morajo vsa dejanja izvajati po $v$ naprej strogo določenih standardih kakovosti. Naša obveza je, da proizvode in procese razvijamo $v$ smeri stalnega izboljševanja kakovosti (Kopperger, 1996, str. 53). Potrebna je tudi opredelitev kakovosti. Kakovost proizvodov in storitev pa lahko določajo proizvajalec ali stranka. $\checkmark$ teoriji celovitega obvladovanja kakovosti pričakovano kakovost določajo stranke (Vahs, 1997, str. 186). Zavedati se moramo, da stranka ni samo končni kupec, ampak so to vsi sodelavci v procesu proizvodnje oz. ustvarjanja storitev. Stanka je potemtakem vsakdo pred in za nami $\vee$ verigi procesa. $V$ javni upravi mora kakovost končnega proizvoda upoštevati želje, korist in potrebe državljanov. Zato je javna uprava pristojna, da z danimi sredstvi čim bolj zadovolji državljana. Navsezadnje je država tista, ki strankam (državljanom) predpisuje postopke. Ljudje sami registracij avtomobilov, gradbenih dovoljenj itd. ne potrebujejo, ampak jih morajo pridobiti, ker je tak upravni postopek. Javna uprava se mora zato zavedati, da je ona tista, ki od ljudi nekaj pričakuje, in da so stranke $v$ uradih zaradi upravnega postopka in ne po lastni želji. 
Načela TQM so se razvila $v$ vsakdanji praksi v podjetjih in drugih organizacijah s ciljem čim bolj zadovoljiti kupca, zato ta teorija ni abstraktna. Ker se je razvijala ad hoc, tudi nima enega vpeljanega načina doseganja boljših rezultatov. TQM se mora prilagoditi vsaki kulturi in zgodovini vsakega posameznega podjetja oz. organizacije. Razlikovati moramo kontrolo kakovosti, kot smo jo poimenovali nekdaj, in sistem celovitega obvladovanja kakovosti. Pri prvi so se ljudje v glavnem ukvarjali s kontrolo kakovosti proizvodov in storitev, druga pa kakovost obravnava drugače. Razlike si poglejmo na sliki 2 (Kopperger, 1996, str. 54):

Slika 2: Primerjava med kontrolo kakovosti in celovitim obvladovanjem kakovosti

\begin{tabular}{|c|c|c|}
\hline & $\begin{array}{c}\text { Kontrola kakovosti } \\
\text { (nekdaj) }\end{array}$ & $\begin{array}{c}\text { Celovito obvladovanje kakovosti } \\
\text { (danes) }\end{array}$ \\
\hline Cilj poslovanja & $\begin{array}{l}\text { - boljši proizvodi } \\
\text { - minimalni proizvodni stroški } \\
\text { - optimalen izpad }\end{array}$ & $\begin{array}{l}\text { - } \quad \text { boljše delovno okolje } \\
\text { - zadovoljevanje stranke } \\
\text { - } \quad \text { velika fleksibilnost }\end{array}$ \\
\hline $\begin{array}{l}\text { Cilj zagotavljanja } \\
\text { kakovosti }\end{array}$ & - dobri proizvodi & - zadovoljitev trga \\
\hline $\begin{array}{l}\text { Organiziranje } \\
\text { zagotavljanja } \\
\text { kakovosti }\end{array}$ & - stroga kontrola & $\begin{array}{l}\text { - zagotavljanje kakovosti kot del } \\
\text { vsakega opravila }\end{array}$ \\
\hline $\begin{array}{l}\text { Odgovornost za } \\
\text { kakovost }\end{array}$ & - kontrolor kvalitete & $\begin{array}{l}\text { - vsi zaposleni pri svojem } \\
\text { opravilu in občasno nadrejeni }\end{array}$ \\
\hline $\begin{array}{l}\text { Metode zagotav- } \\
\text { ljanja kakovosti }\end{array}$ & $\begin{array}{l}\text { - ugotavljanje napak z } \\
\text { opazovanjem } \\
\text { - merjenje } \\
\text { - kontroliranje } \\
\end{array}$ & $\begin{array}{ll}\text { - } & \text { cilj proizvodnja brez napak } \\
\text { - } & \text { izboljševanje procesov } \\
\text { - } & \text { samokontrola } \\
\end{array}$ \\
\hline $\begin{array}{l}\text { Kaj zagotavlja } \\
\text { kakovost }\end{array}$ & - opazovanje proizvoda & - proces in sistem procesov \\
\hline
\end{tabular}

Vir: Kopperger, 1996, str. 54.

Temeljno načelo TQM se skriva $v$ istočasnosti upoštevanja ljudi, procesov in rezultatov. $V$ teoriji poznamo tri temeljna področja, s katerimi se TQM ukvarja (Kovač, 1999, str. 89-118):

1. osredotočenje na stranke,

2. stalno izboljševanje procesa,

3. celovito sodelovanje zaposlenih $v$ timih.

Ljudje so skrita rezerva podjetja in ustanov za konkurenčno prednost in večjo kakovost. Glavna dolžnost menedžmenta je, da bodo zaposleni s svojimi sposobnostmi in znanjem čim bolj prispevali k uspešni izvedbi delovanja organizacije. Timsko delo vodi $v$ hitrejše izboljševanje procesov in $s$ tem kakovost ter poslovne 


\section{Žiga Andoljšek}

\section{Celovito obvladovanje kakovosti v javnem sektorju}

rezultate tako $v$ zasebnem kot tudi javnem sektorju. Potreba državljanov po storitvah javnega sektorja narašča. Javnemu sektorju mnogokrat konkurirajo tudi zasebni subjekti, zato kakovost storitev ne sme izostati. Močno navznoter usmerjena organizirana javna uprava odbija marsikaterega državljana. Sodelovanje med javnim sektorjem in stranko - državljanom - je bilo težko, saj sta bila fleksibilnost in inovativnost $v$ javnem sektorju neznana pojma. Zato je cilj menedžmenta, ki se ukvarja $s$ kakovostjo procesov, jasen: delovanje usmeri na zadovoljevanje potreb strank in še več, prav od začetka do konca procesu poskuša zagotoviti čim večjo kakovost (Kirchhoff, 1996, str. 17). Zato moramo uresničevati dva cilja: tvorno vključevati zaposlene $v$ izboljševanje procesov in procese organizirati zaradi čim boljšega zadovoljevanja potreb državljanov.

Sistem celovitega obvladovanja kakovosti vključuje vsaj naslednje elemente (Pollit, 1995):

1. vnaprej pripravljene cilje glede doseganja kakovosti;

2. prizadevanje vsakega posameznika za čim boljšo kakovost, po vsej organizacijski strukturi od vodstva do najnižjih uslužbencev;

3. naprezanje za izboljšave znotraj podjetja in njihovo obvladovanje, nato pa še obvladovanje okolja;

4. željo po neprestanem izpopolnjevanju;

5. zavezanost neprestanim izboljšavam (TOM je nenehen proces);

6. predvidevanje možnih napak in njihovo preprečevanje.

Le kdo ne bi želel uresničevati navedenih načel! Sklepamo in verjamemo, da nas vodijo k večji učinkovitosti, posledica česar je večja uspešnost. Če verjamemo, da TQM izvira iz zasebnega sektorja, kjer je edino sodilo finančni rezultat, potem bi pozitivne učinke lahko pričakovala tudi javna uprava.

\subsection{Osredotočenje na stranke}

Cilj vsakega gospodarskega subjekta je stranki ponuditi izdelek ali storitev. Vendar je danes zgolj izdelek ali storitev premalo za uspešno poslovanje. Zato je ekonomskim subjektom cilj, da z izdelkom ali storitvijo čim bolj zadovoljijo odjemalčeve potrebe. Če izdelek ali storitev ni narejen po željah kupca, se vrednost proizvoda ali storitve močno zmanjša. Pojmovanje kakovosti se je s tehničnih lastnosti izdelka obrnilo na celovito kakovost, $v$ katero je vključen celotni proces. Tehnične značilnosti niso zanemarjene, dodana pa jim je kakovost procesa, ki odseva medsebojno sodelovanje pri izvajanju procesa, vgrajene materiale, kontrolo in poprodajne storitve. Enostavno moramo v proizvod vključiti tisto, kar bi si sami želeli pri posameznem proizvodu ali storitvi.

$\checkmark$ podjetjih se podjetniki zavedajo, da se razočarana stranka ne bo vrnila. Stranko pritegneš, če ji ponudiš več kot konkurenca glede na njeno zaznavanje 
potreb. Zato ni enotnega vzorca, ki bi jamčil uspešnost prodaje. Treba je proučiti posamezne ciljne trge in za vsakega uporabiti poseben način pristopa in prodaje. Cilj izboljšanja kakovosti storitve bomo dosegli samo, če bomo razumeli želje zunanjih strank in potek procesov $v$ organizaciji, da bi čim bolj zadovoljili zunanje stranke (Munro, 1992, str. 93-144). Zato bi moralo podjetje redno ocenjevati zadovoljstvo svojih strank. Orodja, ki jih imajo na voljo in bi jih bilo mogoče uporabiti tudi v javnem sektorju, so (Kotler, 1996, str. 41-43):

- sistem pritožb in predlogov,

- ankete o zadovoljstvu strank,

- namišljeno nakupovanje (organizacija najema ljudi, ki se pretvarjajo, da so kupci, in poročajo o dobrih in slabih izkušnjah pri nakupovanju izdelkov),

- analiza izgubljenih kupcev (podjetje vzpostavi stik z nekdanjimi kupci in poskuša izvedeti vzrok njihovega nezadovoljstva).

Vendar je filozofija teorije TOM globlja. Teorija ne poudarja samo končnega kupca, ki ga imamo sami največkrat v mislih, ampak dejstva, da ima vsak zaposleni svojega notranjega kupca. Zato je vsak zaposleni notranji dobavitelj in kupec storitev ali proizvodov. Če želimo biti dosledni, je lahko tudi naš končni kupec dobavitelj nekoga tretjega. Če $v$ organizacijah gledajo na medsebojno sodelovanje $v$ procesih tako, kot smo navedli, se kakovost procesa, proizvodov in storitev ter medsebojnega sodelovanja poveča. Delavec, ki prodaja svojo storitev drugemu, se mora postaviti $\vee$ vlogo kupca, saj bo le takrat lahko čim bolj zadovoljil potrebo kupca. če bomo znali prisluhniti potrebam drugega in se poskušali približati njegovim željam, izboljšanje kakovosti ne more izostati. Za ocenitev zadovoljstva pa so povratne informacije kupcev nujne. Tako bi morali razmišljati vsi zaposleni. Teorija TQM pravi, da ima vsak zaposleni dvojno delo: prvič standardno, ki vključuje faze za izdelavo proizvoda ali storitve, in drugič, skrbeti mora za izboljševanje svojega dela.

\subsection{Stalno izboljševanje procesa}

Izboljševanje kakovosti in kupčevega zadovoljstva dosegamo z izboljševanjem procesa. Vsak izdelek in storitev je rezultat procesa. Če želimo izboljšati kakovost, moramo izboljšati proces načrtovanja, nabave, proizvodnje, prodaje in kontrole. Bistvene procese je treba urediti, saj je rezultat odvisen od procesov. Popis in spremljanje procesov $\vee$ organizaciji privede do boljših podrobnih rezultatov. Standardi ISO npr. temeljijo na podobnih predpostavkah. Obvladovanje procesov in sledenje dogajanju $\vee$ organizaciji je bistvenega pomena. Osredotočenje samo na predmete je preživeto.

Menedžment procesa, TQM, ima določeno zaporedje. Prvi je plan izvedbe za dosego cilja, ki obvezno upošteva ljudi. Sami izvedbi sledi stopnja nadziranja skladnosti rezultatov s planom izvedbe. Na podlagi informacij nadzora lahko analiziramo, zakaj je prišlo do odstopanj od plana izvedbe ali zakaj plan izvedbe ni bil primeren. 


\section{Žiga Andoljšek}

\section{Celovito obvladovanje kakovosti v javnem sektorju}

Na podlagi ugotovitev lahko izvršimo revizijo cilja, plana izvedbe ali plana nadzora. $\mathrm{Na}$ tak način je mogoče analizirati vsak proces $v$ podjetju. Razumevanje procesov in njihovo izpopolnjevanje je za uspešnost bistvenega pomena. Samo ob popolnem poznavanju dogajanja v podjetju menedžment ve, kako se odzvati. Miselne simulacije so dobrodošel pripomoček pri uvajanju TOM.

\subsection{Sodelovanje zaposlenih v timih}

Zaposleni so ključni proizvodni dejavnik $v$ storitvenem sektorju. Z ustrezno organizacijo, vodenjem in motiviranjem lahko zaposleni dosežejo neslutene rezultate. Ena izmed oblik sodelovanja je timsko delo. Tim je skupina ljudi z jasno določenim in skupnim ciljem. To ni interesna skupina, ampak skupina ljudi, ki so združeni, da dosežejo cilj - rezultat s čim nižjimi stroški. Ponavadi so v timu ljudje različnih znanj in sposobnosti. Navsezadnje so za uspešen tim pomembne tudi vloge ljudi $v$ timu in ustrezno motiviranje. Pravilna mešanica znanj in osebnostnih lastnosti članov tima pripomore $k$ uspešnosti tima. Združevanje zaposlenih $v$ time ima številne prednosti. Za doseganje čim boljših rezultatov moramo poznati načela izgradnje uspešnega tima (Kovač, 1999, str. 99-110):

- Vsak zaposleni mora biti član vsaj enega tima. Vključevanje $\vee$ tim je obvezno in pri zaposlenem kljub odporu sproži razmišljanje o kulturi tima. Ljudje začno med seboj komunicirati, razreševati konflikte, usklajevati ideje in sami močno vplivati na izboljšave v podjetju.

- Osnovno načelo tima je doseči takšno kakovost dela, da bo stranka zadovoljna. Vsak zaposleni se mora zavedati, da s svojim delom vpliva na zadovoljstvo stranke. Samo povečevanje zadovoljstva privede do pozitivnih rezultatov.

- Razlike $v$ idejah, razmišljanju in mnenjih samo pripomorejo $k$ želenemu rezultatu. Konfliktne situacije so vsakdanjik uspešnih timov. Pestre ideje širijo obzorje.

- Če ima posameznik več znanja, se bo lažje vključil v tim. Dejstvo je, da so znanja posameznika $\vee$ timu delno spregledana ali nefavorizirana, $h$ končnemu rezultatu tima pa močno pripomorejo.

- Vsak zaposleni je specialist na svojem področju. Zato zaposleni najlažje rešujejo probleme na svojih področjih. Če zaposleni lahko izboljšujejo in sodelujejo pri spremembah, se bodo s temi istovetili. Počutili se bodo cenjene in bodo zadovoljni.

- Prikaz rezultatov tima vodi k večji motiviranosti članov tima. Informiranje o poteku del $v$ timu je nujno. Delovna vnema med delom niha, zato neprestano seznanjanje $\mathrm{z}$ doseganjem cilja pripomore $\mathrm{k}$ učinkovitosti članov tima. 
- Ljudje želijo čutiti, da je njihovo delo koristno. Dober vodja zna spodbujati člane in vodi s pohvalami, ne kaznijo.

- Tudi v timu se odvijajo procesi. Tim mora stalno izboljševati svoje procese. Z izboljševanjem procesov tim doseže tudi boljši rezultat.

Ob upoštevanju navedenih načel in pravil za oblikovanje tima smo na dobri poti $k$ boljšim rezultatom organizacije. Vsak tim je uspešen toliko, kolikor so uspešni njegovi člani. Sposobnost posameznika je $v$ primerjavi s sposobnostjo tima zanemarljiva. Zato je vodenje tima nekaj posebnega. Pri vodenju tima veljajo naslednja načela (Rozman, 2000, str. 43-49):

- $\vee$ timu je treba razpravljati, dokler ni doseženo soglasje,

- menjati delo med člani tima,

- iskati vsa dejstva in informacije,

- razpravljati o konfliktih,

- upoštevati »načelo odprtih vrat",

- podeljevati pohvale, graje in priznanja,

- aktivno poslušati člane tima,

- podpirati člane,

- navzven delovati kot tim.

Vodje timov morajo odigrati povezovalno vlogo. Z menedžerskim znanjem lahko iz ljudi, ki so "zlata rezerva", potegnejo maksimum. Ljudje radi delajo $\vee$ timih, le začutiti morajo prednosti take organiziranosti dela.

\section{Celovito obvladovanje kakovosti v javnem sektorju}

$\checkmark$ prejšnjem poglavju smo opisali celovito obvladovanje kakovosti in njegove značilnosti. Navedli smo tri temeljna področja, s katerimi se TQM ukvarja. Prav vse ključne značilnosti omenjenih področij so pomembne tudi pri uvajanju TQM v javni sektor. Pri prenosu teorij in praks iz enega $v$ drugo okolje moramo paziti na značilnosti novega okolja.

Zato bomo $v$ nadaljevanju obravnavanja značilnosti TQM poudarili razlike med zasebnim in javnim sektorjem, ki jih je treba upoštevati. Zahtevajo namreč deloma drugačno uvajanje celovitega obvladovanja kakovosti v javni sektor.

\subsection{Osredotočenje na stranke}

Vsak ekonomski subjekt ne glede na lastniško strukturo deluje za doseganje smotra delovanja. Tega določijo lastniki. Zasebni lastniki si za cilj postavljajo doseganje čim večjega dobička. $\vee$ javnem sektorju pa cilj zamenja zlasti družbena 


\section{Žiga Andoljšek}

\section{Celovito obvladovanje kakovosti v javnem sektorju}

odgovornost. Ta cilj organizacije dosegajo z izvajanjem javnih storitev in proizvodnjo javnih dobrin.

Čeprav so javne storitve praviloma brezplačne, je $v$ zadnjem času zelo poudarjeno osredotočenje na stranke. Prvi vidik kakovosti se nanaša na povečanje kakovosti v organizaciji. Gre za procese v organizaciji, ki zadevajo vse od vodstva do najnižjega uslužbenca. Poudarek je na zadovoljstvu zaposlenih, njihovem izpolnjevanju pričakovanj glede napredovanja in identificiranja s podjetjem. $V$ teoriji se doseganje kakovosti $\vee$ podjetju sliši enostavno, dejstvo pa je, da se $\vee$ organizaciji srečujemo z razkorakom med željami lastnika in zaposlenih. $V$ osnovi gre za asimetrijo informacij. Zaposleni imajo več notranjih, neposrednih znanj iz poslovnega procesa podjetja, lastniki pa imajo moč denarja (Halachmi, 1998, str. 45-56). Prvim je motiv rast, kapitalski donos, prihodki, učinkovitost, kakovost storitev, drugim pa plače in bonitete. Omenjenemu vidiku se tako tudi v javnem sektorju dodaja vidik, ki se nanaša na odnos organizacije do strank.

Ta drugi vidik kakovosti obravnava odnos med proizvajalcem in stranko. Gre za to, da je vse pomembnejša stranka, pri kateri je treba ugotavljati zadovoljstvo in potrebe. Ena izmed metod, ki obravnava to področje, je metoda celovitega obvladovanja kakovosti. Rezultat odličnega pristopa $k$ stranki je večje povpraševanje stranke po javnih storitvah, pa čeprav so omejeno nujne. Rezultat povečanega povpraševanja je več dela $v$ javnih organizacijah. Zdravnik npr. pacientu priporoči izvedbo preiskav, ki niso nujne za zdravljenje.

Tretji vidik kakovosti zadeva doseganje čim večjega standarda $v$ družbi in čim boljšega sodelovanja med državo in državljanom.

Predvsem zaradi tega, ker je teorija prenesena iz zasebnega sektorja, moramo razlikovati pojma stranka in državljan. Pojma stranke v smislu kupca, ki z nakupom pridobi izključno lastninsko pravico, in državljana, ki je potrošnik javnih storitev, je treba med seboj razlikovati. Če je oseba deležna represivnih javnih storitev, npr. aretiranja od policista, plačila kazni za prehitro vožnjo, izpolnjevanja davčne obveznosti itd. težko govorimo o stranki, ampak govorimo o državljanu. Pojem državljan se nanaša na skupek pravic in dolžnosti, ki izvirajo iz ustave in zakonov. Posameznik jih je prisiljen spoštovati in jim podrediti svoje želje. Na drugi strani lahko govorimo o stranki, odjemalcu, porabniku, torej osebi, ki izraža lastne želje in zadovoljstvo ter se lahko individualno odloči za nakup neke dobrine ali ne. $\vee$ ospredje je postavljeno individualno hotenje in osebna odločitev. Stranka je pri izbiri podrejen samo lastni hierarhiji želja in zmožnosti. Državljan je del družbe, stranka pa trga. Stranka je potemtakem le manjši del državljana. TQM posameznika obravnava tradicionalno, kot stranko. »Nova javna uprava" na drugi strani želi stranko postaviti pred državljana, to pomeni pristopiti k obravnavanju posameznika kot družbe in upoštevanju individualnosti.

Nadaljujemo z razlikovanjem med proizvodi in storitvami. Javna podjetja so predvsem $\vee$ zadnjem času zaradi vse večje liberalizacije trgov in privatizacije 
organizacij $\vee$ dobršni meri križanci med zasebnim in javnim sektorjem. Večina se jih že obnaša podobno kot podjetja zasebnega sektorja, prevzemajo njihove tehnike in prakse, zato teh $v$ prispevku ne bomo obravnavali. Glede na to lahko zapišemo, da so preostale organizacije javnega sektorja pretežno storitvene, kar zahteva samosvoje obravnavanje.

Prvič, proizvodi in storitve imajo vsak svoje posebnosti. Storitev je nemogoče proizvajati na zalogo in jo skladiščiti, je enkratna, lastnik storitve pa ostane ponudnik storitve. Storitve so namenjene trenutno za znanega kupca.

Drugič, storitve je težko standardizirati, proizvodov pa ne. $V$ proizvodnji npr. nastane dvesto enakih električnih aparatov. Zaradi subjektivnosti človeka, ki je ponudnik storitev, pa tudi specifičnosti zahtev stranke je storitev unikatna.

Tretjič, proizvod je največkrat zaželen od uporabnika in posredovan od ponudnika. Gre za povezanost dejstva, da sta želji obeh strank usmerjeni v isti cilj. Pri javnih storitvah pa to ne drži vedno. Študent želi npr. opraviti izpit na fakulteti, zato hodi na predavanja, ki so javna in brezplačna; pacient odide k zdravniku, ker želi ozdraveti; kriminalec pa je obsojen zaradi kriminalnega dejanja in je deležen prevzgojitvenih ukrepov. Teh ne prejema po svoji lastni volji in so mu vsiljena. $V$ tem primeru je želja prejemnika storitve obratnosorazmerna z željo ponudnika storitve. Zato bi morali ocenjevati kakovost storitve razumno in z omejitvami glede na naravo storitve.

Nadalje lahko trdimo, da bi moral biti odnos ponudnika storitev do notranjih in zunanjih porabnikov tak kot $\vee$ zasebnem sektorju. Ugotovimo lahko, da to $v$ praksi ne drži. Če sta že zagotovljena komunikacija in sodelovanje med zaposlenimi, pa je komuniciranje z odjemalci $v$ javnem sektorju zelo omejeno. Med vzroki lahko omenimo nepoznavanje odjemalcev in njihovih potreb, relativno težjo določljivost značilnosti, ki govorijo o kakovosti storitve, nezainteresiranost ponudnikov ali odjemalcev za sodelovanje in visoke stroške ugotavljanja kakovosti storitev.

\subsection{Stalno izboljševanje procesa}

Organizacija deluje učinkovito, da bi bila čim uspešnejša. Uspešna pa je, če obvladuje procese, ki $\vee$ njej potekajo. Poleg tega na poslovni izid močno vpliva kakovost storitev.

Obvladovanje procesov pomeni, da so procesi organizirani za doseganje cilja, možno je izboljševanje na poti do cilja, vzpostavljeni so kontrolni in popravljalni ukrepi itd. Na področju reorganizacije javne uprave smo po osebnem mnenju tu verjetno najdlje od uresničitve vseh treh značilnosti TOM. Na ravni države je bil ustanovljen Urad za organizacijo in razvoj uprave, ki je $v$ letošnjem letu izvedel organizacijske reforme javne uprave. Sami procesi v organizacijah pa so stvar vsake organizacije posebej. Prepoznavanje, predvidevanje učinkov sprememb in same 


\section{Žiga Andoljšek}

\section{Celovito obvladovanje kakovosti v javnem sektorju}

spremembe ostajajo na ramenih vsake organizacije posebej. Nekaj organizacij razmišlja o prihodnosti in se že poteguje za certifikat kakovosti procesov $v$ upravi; tako so na pravi poti k izboljšavam.

Samo osredotočenje na stranke in izboljšanje procesov pa je za dosego ciljev organizacije $v$ javnem sektorju premalo. Pojem kakovost je dal zaposlenim $v$ javnem sektorju nov zagon. Na eni strani so bili stimulirani ponudniki storitev, na drugi pa tudi prejemniki, ker so bili zaradi izboljšav deležni boljših storitev. Boljša kakovost pa je imela še dodaten učinek pri ekonomiki. Kakovost in ekonomika se dopolnjujeta.

Kot smo opozorili že prej, je težko ocenjevati kakovost javnih storitev, ki so del kontrolnega aparata države. Ugodnega odziva onesnaževalcev na storitve preprečevanja onesnaževanja npr. ne moremo pričakovati. Kakovosti storitev prevzgojnih zavodov tudi ne bodo nepristransko ocenjevali zaporniki. Pojavlja se problem, da pri nekaterih javnih storitvah ne moremo pričakovati, da bodo tisti, ki so jim te storitve namenjene, dobili povratne informacije o kakovosti in zadovoljstvu. Še posebej je to razvidno pri represivnih storitvah, kjer kakovostnejša storitev bolj krati prejemnikovo svobodo.

Nazadnje imamo pri javnih storitvah problem, da prav ponudniki javnih storitev vzpostavljajo okoliščine za čim redkejše izvajanje javnih storitev. Zdravnik, ki opravlja javno službo zdravljenja, npr. otroku predpiše cepljenje proti nekaterim nalezljivim boleznim. S tem je zmanjšal možnost strankine uporabe zdravstvenih storitev. Pri gasilcih je podobno. Ob vgradnji protipožarnih sistemov se količina storitev, ponujenih od gasilcev, zmanjša. Podobnih primerov je veliko. Navedena dejstva kažejo na to, da je proučevanje kakovosti v javnem sektorju dosti bolj zapleteno kot $\checkmark$ zasebnem.

\subsection{Timsko delovanje}

Pozitivni učinki timskega dela so dokazani. Kot smo opisali, je mogoče timsko delo enako obravnavati tako $v$ zasebnem kot $v$ javnem sektorju. Glavni očitek javnega sektorja je, da je organiziranost $v$ javnem sektorju bolj toga kot $v$ zasebnem. To je ovira, ki slabi učinek timskega dela. Izhajajoč iz teorije, lahko poleg togosti poudarimo tudi premajhno dodatno finančno stimulacijo članov tima. Obema omenjenima slabostma lahko dodamo tudi pomanjkanje vodstvenega znanja vodij v javnem sektorju. Tudi vodje $v$ javnem sektorju bodo morali postati vodje $v$ pravem pomenu besede. Spoznati in uporabljati bodo morali vodstveno znanje, da bodo lahko kakovostno in ciljno usmerjeno načrtovali, organizirali, vodili in kontrolirali.

Čeprav je veliko opravil organov javnega sektorja rutinskih, je kljub temu precej inovativnih oz. razvojnih. Začetke timskega dela lahko zasledimo pri projektnem delu. Ker je projekt enkraten in unikaten dogodek, zahteva sodelovanje večjega števila sodelavcev. Skupina ljudi z različnimi znanji pa naravnost sili v timsko delo. 
Tovrstne pristope lahko opazimo na ministrstvih in drugih organih. Zavedati pa se moramo, da je uspešnost tima odvisna od članov tima in predvsem vodje.

\section{Zaključek}

$\checkmark$ zadnjem času se je razmišljanje $v$ javnem sektorju spremenilo, predvsem z reformo javne uprave in vedno pogostejšim zahtevam po večji učinkovitosti in uspešnosti javnega sektorja. Do nedavnega je bila javna uprava birokratski aparat, ki je bil namenjen pretežno sam sebi. Danes cilj javnega sektorja ni le ustvarjanje javnih storitev za uravnotežen razvoj, marveč je pomembna kakovost procesov, storitev in doseganje čim večje zadovoljitve potreb uporabnikov javnih storitev.

Že nekaj časa javni in zasebni sektor plodno sodelujeta. Dejansko udeležbo zasebnega sektorja pri izvajanju javnih storitev kažeta instrumenta koncesije in javnega naročila. Pri obeh gre predvsem za doseganje večje stroškovne učinkovitosti. Poleg tega pa se prenašajo menedžerski pristopi iz privatnega sektorja $\vee$ javnega. Pri tem obstajajo nekatere omejitve, ki smo jih omenili $\vee$ članku. Zaradi različnosti javnega in zasebnega sektorja je treba teorije, razvite $v$ zasebnem sektorju, delno prilagoditi delovanju javnega sektorja. $S$ tem se korist novih pristopov delno izgubi, glavni prispevek pa še vedno ostane.

$\checkmark$ delu je predstavljeno celovito obvladovanje kakovosti, ki poudarja pomembnost kakovosti procesov, osredotočenost na stranke javnih storitev in sodelovanje zaposlenih s ciljem doseči čim boljši poslovni rezultat. Kadar neko teorijo prenašamo iz javnega $\vee$ zasebni sektor, pa se moramo zavedati tudi razlik. Posebej smo navedli razlike med stranko in državljanom, proizvodom in storitvijo, vodjo zasebnega in javnega sektorja ter timskim delom $v$ privatnem in javnem sektorju. Te so opisane zato, ker $v$ javnem sektorju ne moremo uporabljati enakih pristopov $k$ strankam, vodenja, storitev in ugotavljanja kakovosti kot v zasebnem sektorju.

Ker je bila opisana teorija razvita $\vee$ zasebnem sektorju zaradi izboljšanja poslovanja in je še posebej primerna za storitvene dejavnosti, verjamemo, da jo bodo uporabljali številni menedžerji subjektov javnega sektorja. Zavedati pa se moramo, da prevzem teorije ni dovolj; zahtevano je sodelovanje vseh, tako zaposlenih kot tudi strank. Le z njihovo pomočjo bo zaživela in dosegla svoj cilj: izboljšanje učinkovitosti in uspešnosti javnega sektorja.

\section{Literatura}

- Goller, J. idr. (1996): Verwaltungsmanagement, Stuttgart.

- Hackman, J.R. idr. (1995): Total Quality Management: Empirical, Conceptual and Practical Issues, Administration Science Quarterly, Harvard Business School.

- Halachmi, A. in Boorsma, P. B. (1998): Inter and Intra Government Arrangements for Productivity. Kluwer Academic Publisher, Boston. 
Žiga Andoljšek

Celovito obvladovanje kakovosti v javnem sektorju

- Henry, N. (1999): Public Administration and Public Affairs, 7. izd., Prentice Hall, New Jersey.

- Kirchhoff, G. (1996): Total Quality Management, Ein Innovationskonzept für Kundenorientierte Verwaltungen, Stuttgart.

- Kopperger, G. (1996): TOM und Lean Management als Grundlage zur Entwicklung von Leistungsverwaltungen, in: Modernes Verwaltungsmanagement.

- $\quad$ Kotler, P. (1996): Marketing Management - Trženjsko upravljanje. Ljubljana, Slovenska knjiga.

- Kovač, B. idr. (1999): Sodobne oblike in pristopi pri organiziranju. Moderna organizacija, Kranj.

- Marolt, J. (1994): Menedžment in tehnologija zagotavljanja kvalitete. Moderna organizacija, Kranj.

- Munro-Faure, L. in Munro-Faure, M. (1992): Implementing Total Quality Management, Financial Times/Pitman Publishing, London.

- Pollit, C. idr. (1995): Quality Improvement in European Public Services: Concepts, Cases and Commentary, SAGE, London.

- Rozman, R. (2000): Ravnanje projekta. Ekonomska fakulteta, Ljubljana.

- Vahs, D. (1997): Organisation, Einführung in die Organisationstheorie und Praxis, Stuttgart.

- Verbič, B. (1994): Dobrodošli med najboljšimi. Gospodarski vestnik, Ljubljana.

- Žnidaršlč, J. idr. (1990): Razumevanje kakovosti. Gospodarski vestnik, Ljubljana.

Žiga Andoljšek je magister ekonomskih znanosti. Zaposlen je na Fakulteti za upravo v Ljubljani, kjer poučuje predmet Statistika. V svojem raziskovalnem delu se ukvarja s proučevanjem učinkovitosti in uspešnosti v javnem sektorju.

\section{SUMMARY}

\section{Total Quality Management in the Public Sector}

The aim of this article is to present the theory of Total Quality Management (TOM ) in the public sector, focusing on the particular features of the public sector. TOM is a collection of principles and techniques for the constant development of processes in organizations, from the lowest to highest levels. Its aim is to ensure that clients are fully satisfied with the quality of products, processes, organization and its employees. Constant development together with encouraging employees for problem solving lead the organization on a path of effectiveness and efficiency.

The theory of TOM was developed in the private sector. Taking into account some particular features of the public sector, the TOM theory can be applied there. The quality system is a process of constant improvements changing inputs to outputs. TQM functions not only inside the organization but also outside it. TOM is defined as a developing system that focuses on satisfying 
clients' needs, aims at assuring effectiveness and efficiency of organization, and encourages its employees to achieve the best results.

The main principle of TQM is to simultaneously consider three aspects, which are: people, processes and results. In theory, three main aspects are very important:

- focus on the client,

- constant improvement of processes,

- cooperation between employees within teams.

Because the TOM theory was developed in the private sector, some particular features of the public sector must be taken into account. The first is the distinction between clients and citizens. Secondly, we must be aware of the difference between products and services. Thirdly, there is also the difference between private and public services.

Public administration in Slovenia is undoubtedly undergoing major changes. The theory presented in this article is one of the many possible ways to improve its quality. Because TQM was developed in the public sector, we argue that it is one of the ways leading to a greater efficiency and effectiveness of the public sector. 